\title{
Comparative efficacies of commercially available benzimidazoles against Pseudodactylogyrus infestations in eels
}

\author{
K. Buchmann ${ }^{1}$, J. Bjerregaard ${ }^{2}$ \\ ${ }^{1}$ Department of Fish Diseases, Royal Veterinary and Agricultural University, 13 Bülowsvej, DK-1870 Frederiksberg C, \\ Denmark \\ ${ }^{2}$ Department of Pharmacy, Royal Veterinary and Agricultural University, 13 Bülowsvej, DK-1870 Frederiksberg C, Denmark
}

\begin{abstract}
The antiparasitic efficacies of 9 benzimidazoles in commercially available formulations were tested (water bath treatments) on small pigmented eels Anguilla anguilla, experimentally infected by 30 to 140 specimens of Pseudodactylogyrus spp. (Monogenea). Exposure time was $24 \mathrm{~h}$ and eels were examined 4 to $5 \mathrm{~d}$ post treatment. Mebendazole (Vermox; $1 \mathrm{mg} \mathrm{l}^{-1}$ ) eradicated all parasites, whereas luxabendazole (pure substance) and albendazole (Valbazen) were $100 \%$ effective only at a concentration of $10 \mathrm{mg} \mathrm{l}^{-1}$. Flubendazole (Flubenol), fenbendazole (Panacur) and oxibendazole (Loditac) (10 $\mathrm{mg}^{-1}$ ) caused a reduction of the infection level to a larger extent than did triclabendazole (Fasinex) and parbendazole (Helmatac). Thiabendazole (Equizole), even at a concentration as high as $100 \mathrm{mg} \mathrm{l}^{-1}$, was without effect on Pseudodactylogyrus spp.
\end{abstract}

\section{INTRODUCTION}

The broad spectrum anthelmintic drug mebendazole was reported as an efficacious compound against infestations of the European eel Anguilla anguilla with gill parasitic monogeneans of the genus Pseudodactylogyrus (Székely \& Molnar 1987, Buchmann \& Bjerregaard 1989, 1990, Mellergaard 1989). As benzimidazoles share many molecular features and action mechanisms (Vanden Bossche 1985), other representatives of this drug group are also likely to have an effect on these parasites. The present paper reports on trials with 9 different benzimidazoles for this host-parasite system.

The increasing use of mebendazole in eel farms imposes a risk for selection of drug resistant parasites. Side resistance, defined as resistance to another compound belonging to the same drug group (Waller 1985), to other benzimidazoles would then be expected to occur, as this type of resistance has been recorded in parasitic nematodes (Martin 1985). However, side resistance could only be properly evaluated if trials with these benzimidazoles have been conducted on a susceptible, anthelmintic-naive parasite population. This trial also serves as a base-line study to determine the susceptibility of such a parasite population to a range of commercially available benzimidazole compounds. If drug resistance will develop under practical eel-farm conditions in the future, it is likely to be recognized during treatments with commercially available drug formulations. Therefore this type of drug preparations were used in the present study.

\section{MATERIALS AND METHODS}

Eels. Batches, each comprising 10 specimens of small pigmented eels Anguilla anguilla (total body length 8 to $16 \mathrm{~cm}$ and body weight 0.7 to $5.5 \mathrm{~g}$ ) were exposed to aerated drug solutions $(71)$ at 24 to $25^{\circ} \mathrm{C}$ in plastic aquaria (volume $17 \mathrm{l}$ ). Eels were exposed for $24 \mathrm{~h}$ whereafter they were transferred to clean aquaria with pure aerated tap water at the same temperature. After 4 to $5 \mathrm{~d}$ they were examined for Pseudodactylogyrus spp. as described by Buchmann (1988a). These eels had been kept in a parasite-free fish tank for 2 mo and were infected before the experiments as described below. Two batches of eels were incubated in pure tap water and kept as untreated controls. For each trial, the body length and weight of examined eels were recorded (Table 1) together with prevalence (percentage of hosts infected) and abundance (mean number of 
parasites per host - infected and uninfected) calculated according to Margolis et al. (1982). Only surviving eels were examined.

Parasites. A mixed population of Pseudodactylogyrus anguillae and $P$. bini on larger eels $(10$ to $20 \mathrm{~g}$ body weight) were maintained in a $250 \mathrm{l}$ aquarium $\left(25^{\circ} \mathrm{C}\right)$. This population of parasites has never been treated with drugs and an infection pressure occurs in the aquarium. The formerly uninfected eels were placed in small net cages (Buchmann 1988b) and submerged in the aquarium for $6 \mathrm{~d}$, whereby all eels became infected ( 30 to 140 parasites eel ${ }^{-1}$ ). The trials were conducted 14 to $20 \mathrm{~d}$ post-infection.

Drugs. The drug concentrations used are listed in Table 1. With one cxception (luxabendazole), where pure substance was used with acetone as solvent, the drug preparations were the commercially available products: aibendazole (Vaibazen vei. suspension $19 \mathrm{mg} \mathrm{ml} \mathrm{ml}^{-1}$ ), fenbendazole (Panacur suspension $100 \mathrm{mg} \mathrm{ml}^{-1}$ ), flubendazole (Flubenol $50 \mathrm{mg} \mathrm{g}^{-1}$ ), luxabendazole (pure substance), mebendazole (Vermox suspension $50 \mathrm{mg} \mathrm{ml}^{-1}$ ), oxibendazole (Loditac vet. 50 $\mathrm{mg} \mathrm{g^{-1 }}$ ), parbendazole (Helmatac vet. $300 \mathrm{mg} \mathrm{g}^{-1}$ ), thiabendazole (Equizole $330 \mathrm{mg} \mathrm{g}^{-1}$ ) and triclabendazole (Fasinex suspension $100 \mathrm{mg} \mathrm{m}^{-1}$ ).

\section{RESULTS}

\section{Anthelmintic efficacy}

It was found that exposure to mebendazole $\left(1 \mathrm{mg} \mathrm{l}^{-1}\right)$ for $24 \mathrm{~h}$ was $100 \%$ effective in parasite eradication. Luxabendazole was nearly as efficacious: only one parasite was found in 8 eels after treatment with $1 \mathrm{mg}$ $1^{-1}$. Albendazole and flubendazole had some effect at this concentration, but parasite eradication was only accomplished for albendazole, as for luxabendazole, at $10 \mathrm{mg} \mathrm{l}^{-1}$.

A reduction of the infection level, without total parasiticidal effect, was found with exposure for $24 \mathrm{~h}$ with $10 \mathrm{mg} \mathrm{\textrm {l } ^ { - 1 }}$ of the compounds flubendazole, oxibendazole and fenbendazole. A less convincing reduction was seen after treatment with triclabendazole $(10 \mathrm{mg}$ $\mathrm{1}^{-1}$ ) and parbendazole $\left(5 \mathrm{mg} \mathrm{l}^{-1}\right)$. The latter drug had a better, but still inadequate, effect at a concentration of $50 \mathrm{mg} \mathrm{l}^{-1}$. Even with a concentration of thiabendazole as high as $100 \mathrm{mg} \mathrm{l}^{-1}$ no reduction of the infection level was found (Table 1).

\section{Toxicity observations}

Thiabendazole (both 10 and $100 \mathrm{mg} \mathrm{l}^{-1}$ ) elicited escape reactions in eels a few seconds after exposure.
After few hours eels turned sluggish and lay on their side or back on the bottom of the aquaria, until they were removed from the medicated water However the mortality during the 4-d observation period was low (Table 1). The other drugs elicited no immediate adverse reactions, but a high mortality ( 4 of 10 ) in the oxibendazole group (10 $\left.\mathrm{mg} \mathrm{l}^{-1}\right)$ was noted by $4 \mathrm{~d}$ posttreatment.

\section{DISCUSSION}

With the exception of luxabendazole, the benzimidazoles used in this investigation were the commercially available preparations, including their vehicles. As additions may influence to a greater or lesser extent, the suspension of drugs in water, it should be stressed that the present comparative study is on the commercially available products and their vohicles. These can be ranked after decreasing potency on Pseudodactylogyrus spp. It was found that mebendazole (Vermox) was the most potent drug and our results confirm work of Székely \& Molnar (1987), Buchmann \& Bjerregaard $(1989,1990)$ and Mellergaard (1989). However luxabendazole (with acetone as solvent) and albendazole (Valbazen) also showed efficacy against infections with Pseudodactylogyrus spp. When fenbendazole, flubendazole and oxibendazole, in their commercially available formulations, were used in water bath treatments with $10 \mathrm{mg} \mathrm{l}^{-1}$ of the drug, only a reduction of the infection level was seen. At this concentration triclabendazole treatment only elicited a slight reduction of the infection, and parbendazole (Helmatac) could only reduce the infection level at a concentration as high as $50 \mathrm{mg} \mathrm{l}^{-1}$. Thiabendazole had no effect even at $100 \mathrm{mg} \mathrm{l}^{-1}$ and elicited acute toxic symptoms in the eels.

Because of the unknown influence of the vehicles in the different benzimidazole-products on drug suspension in water and penetration of drug into the parasite, it is not possible to make clear conclusions about the different pure compounds' action in the monogeneans. However, it is noteworthy that the benzimidazoles with the best effect on Pseudodactylogyrus spp. all have substitutions with methyl carbamate in the 2-position of the molecule. Thiabendazole and triclabendazole are both without the carbamate moiety and have no or little effect on the parasites. The substitutions at the 5 position differ markedly between the 3 most potent benzimidazoles, mebendazole, luxabendazole and albendazole, and future research should elucidate the importance, if any, of this part of the molecule on the gill parasites. The major target for benzimidazoles' action seems to be the microtubule system (Behm \& Bryant 1985, Vanden Bossche 1985, Roberson 1988). Triclabendazole, which differs structurally from other 
Table 1 Anguilla anguilla. Level of parasitization with Pseudodactylogyrus spp. after exposure to various benzimidazoles. Only surviving eels were examined. Length and weight of eels presented

\begin{tabular}{|c|c|c|c|c|c|c|}
\hline \multirow[t]{2}{*}{ Drug } & \multirow{2}{*}{$\begin{array}{l}\text { Conc. } \\
\left(m g l^{-1}\right)\end{array}$} & \multirow{2}{*}{$\begin{array}{l}\text { No. } \\
\text { eels }\end{array}$} & \multirow{2}{*}{$\begin{array}{c}\text { Body length }(\mathrm{cm}) \\
\frac{\mathrm{x}}{(\mathrm{SD})}\end{array}$} & \multirow{2}{*}{$\begin{array}{c}\text { Body weight }(g) \\
\bar{x}(\mathrm{SD})\end{array}$} & \multicolumn{2}{|c|}{ After treatment } \\
\hline & & & & & $\begin{array}{c}\text { Prevalence } \\
\qquad(\%)\end{array}$ & $\begin{array}{c}\text { Abundance } \\
\text { (SD) }\end{array}$ \\
\hline $\begin{array}{l}\text { Albendazole } \\
\text { (Valbazen) }\end{array}$ & $\begin{array}{r}1 \\
10 \\
100\end{array}$ & $\begin{array}{l}10 \\
10 \\
10\end{array}$ & $\begin{array}{ll}11.0 & (2.4) \\
12.4 & (3.4) \\
10.2 & (1.0)\end{array}$ & $\begin{array}{ll}1.5 & (1.3) \\
2.5 & (2.6) \\
1.1 & (0.4)\end{array}$ & $\begin{array}{r}100 \\
0 \\
0\end{array}$ & $\begin{array}{cl}28.3 & (26.2) \\
0.0 & (0.0) \\
0.0 & (0.0)\end{array}$ \\
\hline $\begin{array}{l}\text { Fenbendazole } \\
\text { (Panacur) }\end{array}$ & $\begin{array}{r}1 \\
10\end{array}$ & $\begin{array}{r}10 \\
8\end{array}$ & $\begin{array}{ll}12.7 & (2.7) \\
12.8 & (2.6)\end{array}$ & $\begin{array}{ll}2.4 & (1.7) \\
2.5 & (1.3)\end{array}$ & $\begin{array}{r}100 \\
63\end{array}$ & $\begin{aligned} 45.6 & (43.0) \\
6.0 & (10.5)\end{aligned}$ \\
\hline $\begin{array}{l}\text { Flubendazole } \\
\text { (Flubenol) }\end{array}$ & $\begin{array}{r}1 \\
10\end{array}$ & $\begin{array}{r}10 \\
9\end{array}$ & $\begin{array}{l}13.8(4.4) \\
12.9(1.5)\end{array}$ & $\begin{array}{ll}3.6 & (2.7) \\
2.3 & (1.1)\end{array}$ & $\begin{array}{r}100 \\
33\end{array}$ & $\begin{array}{ll}16.7 & (8.9) \\
10.9 & (17.5)\end{array}$ \\
\hline $\begin{array}{l}\text { Luxabendazole } \\
\text { (pure substance) }\end{array}$ & $\begin{array}{r}1 \\
10 \\
100\end{array}$ & $\begin{array}{r}8 \\
10 \\
8\end{array}$ & $\begin{array}{r}9.5(1.7) \\
13.2(2.6) \\
12.2(2.9)\end{array}$ & $\begin{array}{ll}1.0 & (0.6) \\
2.8 & (2.1) \\
2.3 & (2.0)\end{array}$ & $\begin{array}{r}13 \\
0 \\
0\end{array}$ & $\begin{array}{ll}0.1 & (0.4) \\
0.0 & (0.0) \\
0.0 & (0.0)\end{array}$ \\
\hline $\begin{array}{l}\text { Mebendazole } \\
\text { (Vermox) }\end{array}$ & 1 & 9 & $10.9(2.1)$ & $1.6(1.2)$ & 0 & $0.0(0.0)$ \\
\hline $\begin{array}{l}\text { Oxibendazole } \\
\text { (Loditac) }\end{array}$ & $\begin{array}{r}1 \\
10\end{array}$ & $\begin{array}{l}8 \\
6\end{array}$ & $\begin{array}{l}10.6(1.5) \\
10.5(2.4)\end{array}$ & $\begin{array}{ll}1.2 & (0.5) \\
1.6 & (1.3)\end{array}$ & $\begin{array}{l}100 \\
100\end{array}$ & $\begin{array}{ll}35.3 & (15.7) \\
16.6 & (10.1)\end{array}$ \\
\hline $\begin{array}{l}\text { Parbendazole } \\
\text { (Helmatac) }\end{array}$ & $\begin{array}{r}5 \\
50\end{array}$ & $\begin{array}{r}10 \\
8\end{array}$ & $\begin{array}{l}11.5(3.6) \\
11.1(2.2)\end{array}$ & $\begin{array}{ll}1.7 & (1.8) \\
1.7 & (0.9)\end{array}$ & $\begin{array}{r}100 \\
88\end{array}$ & $\begin{array}{cl}50.2 & (47.8) \\
4.9 & (4.7)\end{array}$ \\
\hline $\begin{array}{l}\text { Thiabendazole } \\
\text { (Equizole) }\end{array}$ & $\begin{array}{r}10 \\
100\end{array}$ & $\begin{array}{r}10 \\
9\end{array}$ & $\begin{array}{ll}13.1 & (1.6) \\
13.3(2.7)\end{array}$ & $\begin{array}{ll}2.5 & (0.8) \\
2.4 & (1.3)\end{array}$ & $\begin{array}{l}100 \\
100\end{array}$ & $\begin{array}{ll}87.0 & (28.8) \\
60.2 & (26.6)\end{array}$ \\
\hline $\begin{array}{l}\text { Triclabendazole } \\
\text { (Fasinex) }\end{array}$ & $\begin{array}{r}1 \\
10\end{array}$ & $\begin{array}{l}10 \\
10\end{array}$ & $\begin{array}{l}13.1(2.1) \\
12.5(2.7)\end{array}$ & $\begin{array}{ll}2.6 & (1.3) \\
2.1 & (1.0)\end{array}$ & $\begin{array}{l}100 \\
100\end{array}$ & $\begin{array}{ll}74.2 & (40.9) \\
58.0 & (44.8)\end{array}$ \\
\hline $\begin{array}{l}\text { Control } 1 \\
\text { Control } 2\end{array}$ & $\begin{array}{l}- \\
-\end{array}$ & $\begin{array}{r}10 \\
9\end{array}$ & $\begin{array}{l}12.6(3.0) \\
12.5(1.9)\end{array}$ & $\begin{array}{ll}2.6 & (2.2) \\
2.2 & (1.1)\end{array}$ & $\begin{array}{l}100 \\
100\end{array}$ & $\begin{array}{ll}86.6 & (50.4) \\
77.4 & (27.9)\end{array}$ \\
\hline
\end{tabular}

benzimidazoles, has been suggested to act on a number of targets in the liver fluke (Bennett \& Köhler 1987). The cumulative effect could thus result in the killing of the parasite. In addition, mitochondrial electron transport is also inhibited by thiabendazole (Köhler \& Bachmann 1987), and Sarwal et al. (1989) found that enzymes of lipid metabolism are affected by thiabendazole and fenbendazole. Future research should elucidate the exact action mechanisms of benzimidazoles in Pseudodactylogyrus spp.

Mebendazole has proved to be a safe and useful anthelmintic against pseudodactylogyrosis in intensive eel-farming enterprises based on recirculated water (Buchmann \& Bjerregaard 1989, 1990), and the drug is now commonly used. However, resistance to anthelmintics in parasitic helminths is an increasing problem in livestock (for review see Anderson \& Waller 1985), and the risk of selection of mebendazole-resistant monogeneans exists if indiscriminate use of this drug occurs in eel-farms. Side resistance to other benzimidazoles might then be expected. If the failing effect of other commercially available benzimidazoles is recorded by eel-farmers after resistance has evolved, side resistance would then be a tempting explanation.
However, based on the present investigations, parasites which are susceptible to mebendazole (Vermox) will not be affected by thiabendazole (Equizole) and triclabendazole (Fasinex). In addition only a lesser effect was found with fenbendazole (Panacur), flubendazole (Flubenol), oxibendazole (Loditac) and parbendazole (Helmatac). The importance of the vehicles for the anthelmintic effect of these preparations (drug suspension, parasite penetration) should be investigated. Also it will be relevant to investigate if mebendazoleresistant gill-parasites, if these will evolve, also have lost susceptibility to luxabendazole and albendazole. Finally it should be accentuated that before luxabendazole and albendazole can be recommended for treatment of pseudodactylogyrosis in intensive eel-farming enterprises, controlled investigations on long-term toxicity and the impact on biological and physico-chemical parameters in the farms should be conducted, as our results only were based on short term laboratory experiments.

Acknowledgements. This investigation was supported by a grant from the Danish Agricultural and Veterinary Research. Council. 


\section{NOTE ADDED IN PROOF}

In further studies with pure drug substances and formic acid as solvent, it was found that luxabendazole and flubendazole $\left(1 \mathrm{mg} \mathrm{l}^{-1}\right)$ eradicated the parasites from lightly infected small eels labundance (SD): $7 \cdot 6$ (7.2)]. In addition it was confirmed that albendazole only had $100 \%$ efficacy in a concentration of $10 \mathrm{mg} \mathrm{l}^{-1}$.

\section{LITERATURE CITED}

Anderson, N., Waller, P. J. (Eds.) (1985). Resistance in Nematodes to anthelmintic drugs. CSIRO Division of Animal Health, Glebe, Australia

Behm, C. A., Bryant, C. (1985). The modes of action of some modern anthelmintics In: Anderson, N., Waller, P. J. (eds.). Resistance in Nematodes to anthelmintic drugs. CSIRO Division of Animal Health, Glebe, Australia

Benneti, J. L., Köhler, P. (1987). Fasciola hepatica: action in vitro of triciabendazole on immature and adult stages. Expl Parasit. 63: 49-67

Buchmann, K. (1988a). Spatial distribution of Pseudodactylogyrus anguillae and $P$, bini (Monogenea) on the gills of the European eel, Anguilla anguilla. J. Fish Biol. 32: 801-802

Buchmann, K. (1988b). Epidemiology of pseudodactylogyrosis in an intensive eel-culture system. Dis. aquat. Org. 5: $81-85$

Buchmann, K., Bjerregaard, J. (1989). Effects of mebendazole on Pseudodactylogyrus spp. from Anguilla anguilla and on the microflora and microfauna in an intensive eel-culture system. In: Fagerholm, M. P. (ed.) Proc. 14th Scand. Symp. Parasit. Elsinore Denmark, August 2-4, 1989. Aabo, Finland

Buchmann, K., Bjerregaard, J. (1990). Mebendazole-treatment

Responsible Subject Editor: Professor W. Körting, Hannover, Germany of pseudodactylogyrosis in an intensive eel-culture system. Aquaculture 86: 139-153

Köhler, P., Bachmann, R. (1978). The effects of the antiparasitic drugs levamisole, thiabendazole, praziquantel, and chloroquine on mitochondrial electron transport in muscle tissue from Ascaris suum. Molec. Pharmac. 14: $155-163$

Margolis, L., Esch, G. W., Holmes, J. C., Kuris, A. M., Schad, G. A. (1982). The use of ecological terms in parasitology (report of an ad hoc commitee of the American Society of Parasitologists). J. Parasitol. 68: 131-133

Martin, P. J. (1985). Nematode control schemes and anthelmintic resistance. In: Anderson, N., Waller, P. J. (eds.). Resistance in nematodes to anthelmintic drugs. CSIRO Division of Animal Health, Glebe, Australia

Mellergaard, S. (1989). Mebendazole treatment against Pseudodactylogyrus infections in eel. In: Fagerholm, M. P. (ed.) Proc. 14th Scand. Symp. Parasit. Elsinore, Denmark, August 2-4, 1989, Aabo, Finland

Roberson, E. L. (1988). Antinematodal drugs. In: Booth, N. H. McDonald, L. E. (eds.). Veterinary pharmacology and therapeutics, 5th edn. Iowa Statc University Press, Ames. Ephrata, Pa

Sarwal, R., Sanyai, S. N., Khera, S. (1989). In vitro effect of benzimidazole drugs on the enzymes of lipid metabolism in Trichuris globulosa. J. Parasitol. 75: 808-810

Székely, Cs., Molnar, K. (1987). Mebendazole is an efficacious drug against pseudodactylogyrosis in the European eel (Anguilla anguilla). J. appl. Ichthyol. 3: 183-186

Vanden Bossche, H. (1985). Pharmacology of anthelmintics. In. Vanden Bossche, H., Thienpont, D., Janssens, P. G. (eds.) Chemotherapy of gastrointestinal helminths. Springer Verlag, Berlin

Waller, P. J. (1985). Resistance to anthelmintics and the implications for animal production. In: Anderson, N., Waller, P. J. (eds.) Resistance in nematodes to anthelmintic drugs. CSIRO Division of Animal Health, Glebe, Australia

Manuscript first received: January 11, 1990

Revised version accepted: June 19, 1990 